Check for updates

Cite this: RSC Adv., 2017, 7, 40965

Received 8th July 2017

Accepted 14th August 2017

DOI: 10.1039/c7ra07521a

rsc.li/rsc-advances

\section{Facile shape-controlled synthesis of lanthanum oxide with different hierarchical micro/ nanostructures for antibacterial activity based on phosphate removal}

\begin{abstract}
Jing Liu, $\dagger^{\mathrm{ab}}$ Ge Wang, $\hat{\dagger}^{\mathrm{ac}} \mathrm{Li} \mathrm{Lu}^{\mathrm{a}}$ Yuming Guo ${ }^{\mathrm{ab}}$ and Lin Yang (iD *ab
In this study, three $\mathrm{La}_{2} \mathrm{O}_{3}$ hierarchical micro/nanostructures, nanospindles, nanopolyhedra and nanospheres, were synthesized to remove phosphate from microbial growth media for bacterial inactivation as an antimicrobial strategy. The experiment results showed that the morphology of $\mathrm{La}_{2} \mathrm{O}_{3}$ hierarchical micro/nanostructures can be controlled by the concentration of the reactants, reaction temperature and cooling treatment. Meanwhile, the properties of the $\mathrm{La}_{2} \mathrm{O}_{3}$ were researched for phosphate removal and antibacterial activity. The results showed that the different morphologies of the $\mathrm{La}_{2} \mathrm{O}_{3}$ micro/nanostructures had different removal abilities for phosphate, and can differently inhibit growth of bacteria. Spherical $\mathrm{La}_{2} \mathrm{O}_{3}$ possesses the best removal ability and antibacterial activity, which indicates that the smaller the $\mathrm{La}_{2} \mathrm{O}_{3}$ hierarchical micro/nanoparticles are, the stronger the phosphate removal capacity. Compared with nanoparticles, the hierarchical micro/nanoparticles have a significant advantage: they not only have the properties of nanoparticles, but also are relatively stable, not easy to aggregate, and are easy to separate after the reaction. Therefore, the $\mathrm{La}_{2} \mathrm{O}_{3}$ hierarchical micronanomaterials may have very good application prospects for phosphate reduction in open water and to inhibit algae overgrowth.
\end{abstract}

\section{Introduction}

Recently, lanthanum compounds have attracted considerable attention in hydrogen storage, electrode and sorbent materials, gate insulators and superconductors due to their versatility and multifunctionality. ${ }^{1-4}$ Meanwhile, it is known that lanthanum compounds, such as lanthanum carbonate $\left(\mathrm{La}_{2} \mathrm{CO}_{3}\right)$, lanthanum hydroxide $\left(\mathrm{La}(\mathrm{OH})_{3}\right)$, lanthanum oxide carbonate $\left(\mathrm{La}_{2} \mathrm{O}_{2} \mathrm{CO}_{3}\right),{ }^{5-7}$ and mixtures of lanthanum compounds $\left(\mathrm{La}_{2} \mathrm{O}_{3}\right.$, $\mathrm{La}_{2} \mathrm{O}_{2} \mathrm{CO}_{3}$ and $\left.\mathrm{La}_{2}(\mathrm{OH})_{3}\right),{ }^{8}$ can bind to phosphate so strongly that they can form $\mathrm{LaPO}_{4}$ and remove excess phosphate in bacterial or algal growth media, ${ }^{8}$ and lead to inhibit the growth of microorganisms and algae. As a typical representative, lanthanum carbonate has been developed as a medicine to reduce the excess phosphate in the human body. ${ }^{9}$ Based on the

${ }^{a}$ Collaborative Innovation Center of Henan Province for Green Manufacturing of Fine Chemicals, Key Laboratory of Green Chemical Media and Reactions, Ministry of Education, School of Chemistry and Chemical Engineering, Henan Normal University, Xinxiang, Henan 453007, P. R. China. E-mail: yanglin1819@163.com

${ }^{b}$ Henan Key Laboratory of Green Chemical Media and Reactions, Henan Key Laboratory of Boron Chemistry and Advanced Energy Materials, Henan Normal University, Xinxiang, Henan 453007, P. R. China

${ }^{c}$ School of Basic Medical Sciences, Xinxiang Medical University, Xinxiang, Henan 453003, P. R. China

$\dagger$ These authors contributed equally to this work. existing reports on bacterial and algal limitation utilizing lanthanum species, ${ }^{10-12}$ we here synthesize three $\mathrm{La}_{2} \mathrm{O}_{3}$ hierarchical micro/nanostructures and investigate their phosphate removal ability and antibacterial activity.

It is widely accepted that phosphate is essential for growth of all organisms and serves as the main building block for nucleic acids, proteins, and energy carriers. ${ }^{13}$ Phosphate is the only form of phosphorus that can be directly assimilated by microorganisms. Firstly, the initial assimilation of inorganic phosphate for microorganisms proceeds via phosphorylation of ADP, which is affected by phosphate limitation in the environment. ${ }^{5}$ In addition, abundant phosphate is an essential condition to synthesize the cell wall of Gram-positive bacteria and the lipid composition of the membranes of Gram-negative bacteria. It could be affected strikingly within phosphate limitation environment. ${ }^{6}$ Consequently, the lack of phosphate often limits their growth, and efficient phosphate removal in water is expected to be a green strategy to prevent the growth of microorganisms and algae, which would avoid toxic substances released from antibacterial agents. ${ }^{14-16}$ On the other hand, reuse of secondary municipal effluent from wastewater treatment plants in water bodies could effectively alleviate freshwater resource shortage. ${ }^{9}$ During the wastewater treatment, excessive nutrients, e.g. phosphate, must be efficiently removed to prevent eutrophication. ${ }^{17}$ 
Considering the strong combination of lanthanum to phosphate and the valid antimicrobial strategy resulted from nutrient starvation of phosphate removal, it is meaningful to explore a facile, high quality and low cost method to synthesize $\mathrm{La}_{2} \mathrm{O}_{3}$ with micro/nanostructure. In the current study, shapecontrolled $\mathrm{La}_{2} \mathrm{O}_{3}$ hierarchical micro/nanostructures were prepared through the regulation of the concentration of the reactants and the reaction temperature. Three morphologies of $\mathrm{La}_{2} \mathrm{O}_{3}$ micro/nanostructures were obtained, and were utilized to compare antimicrobial activity. The results indicated that lanthanum oxide can provide a broadly applicable antimicrobial strategy.

\section{Experimental section}

\section{Material preparation}

Series of morphologies micro-nanostructures of $\mathrm{La}_{2} \mathrm{O}_{3}$ were synthesized by a simple urea homogeneous precipitation process. All the chemicals, lanthanum nitrate hexahydrate $\mathrm{La}\left(\mathrm{NO}_{3}\right)_{3} \cdot 6 \mathrm{H}_{2} \mathrm{O}$, and urea were of analytical pure grade. The morphologies of $\mathrm{La}_{2} \mathrm{O}_{3}$ were controlled by the adjustment of the concentration of the reactants and the reaction temperature. The synthesis process consists of two steps: synthesis of $\mathrm{La}(\mathrm{OH})$ $\mathrm{CO}_{3}$ precursor and $\mathrm{La}_{2} \mathrm{O}_{3}$ product. Firstly, spindle $\mathrm{La}(\mathrm{OH}) \mathrm{CO}_{3}$ was synthesized at $90{ }^{\circ} \mathrm{C}$ with the concentration ratio of $1: 2$ between $\mathrm{La}\left(\mathrm{NO}_{3}\right)_{3}$ and $\mathrm{CO}\left(\mathrm{NH}_{2}\right)_{2}$. While polyhedron $\mathrm{La}(\mathrm{OH})$ $\mathrm{CO}_{3}$ were prepared at $125^{\circ} \mathrm{C}$ with the concentration ratio of $1: 6$ between $\mathrm{La}\left(\mathrm{NO}_{3}\right)_{3}$ and $\mathrm{CO}\left(\mathrm{NH}_{2}\right)_{2}$. In the same manner, when the concentration ratio between $\mathrm{La}\left(\mathrm{NO}_{3}\right)_{3}$ and $\mathrm{CO}\left(\mathrm{NH}_{2}\right)_{2}$ is $1: 400$, spherical $\mathrm{La}(\mathrm{OH}) \mathrm{CO}_{3}$ was successfully synthesized at $85{ }^{\circ} \mathrm{C}$. Subsequently, the $\mathrm{La}(\mathrm{OH}) \mathrm{CO}_{3}$ precursor was calcined from room temperature to $800{ }^{\circ} \mathrm{C}$ with a heating rate of $1{ }^{\circ} \mathrm{C}$ $\min ^{-1}$ and maintained at this temperature for $4 \mathrm{~h}$. Then spherical micro/nanostructures $\mathrm{La}_{2} \mathrm{O}_{3}$ were obtained. Other $\mathrm{La}_{2} \mathrm{O}_{3}$ (spindles, polyhedrons) samples were prepared by a similar procedure with different $\mathrm{La}(\mathrm{OH}) \mathrm{CO}_{3}$ precursors.

\section{Characterization}

XRD measurements were determined using a D8 ADVANCE $\mathrm{X}$-ray diffractometer at a scanning rate of $15^{\circ} \mathrm{min}^{-1}$ in the $2 \theta$ range from $10-80^{\circ}$, with graphite monochromatic $\mathrm{Cu}$ Ka radiation $(\lambda=0.15405 \mathrm{~nm})$. Perking-Elmer 580B infrared spectrophotometer was used to measure Fourier transform infrared spectroscopy (FT-IR) spectra with the $\mathrm{KBr}$ pellet technique. Thermogravimetric and differential thermal analysis (TG-DTA) data were recorded with Thermal Analysis instrument (SDT 2960, TA Instruments, New Castle, DE) with the heating rate of

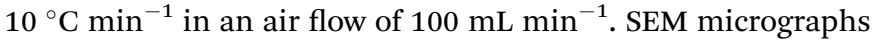
were obtained using a field emission scanning electron microscope (FE-SEM, S-4800, Hitachi). Microstructures and morphologies were investigated using scanning electronic microscopy (SEM, JEOL JSM-6390LV), transmission electron microscope (TEM, JEM-2100) and field emission scanning electron microscopy (FESEM, SUPRA40). All the measurements were performed at room temperature (RT). Brunauer-EmmettTeller (BET) (Tristar Micromeritics, Norcross, GA, USA) method was used to determine the specific surface area at $77 \mathrm{~K}$. The BET analysis was measured after out gassing for 90 minutes at $250{ }^{\circ} \mathrm{C}$.

\section{Phosphate absorption capacity of lanthanum oxide nanoparticles and antibacterial activity}

To evaluate the binding affinity of the nanoparticles to phosphate, $\mathrm{PO}_{4}{ }^{3-}$ was tested by colorimetry assay. Firstly, standard curve was drawn. Secondly, residual $\mathrm{PO}_{4}{ }^{3-}$ was determined. Specifically, $10 \%$ ascorbic acid was freshly prepared as follow: $10 \mathrm{~g}$ ascorbic acid was dissolved in $100 \mathrm{~mL} \mathrm{ddH}_{2} \mathrm{O}$. Then molybdate solution were prepared as follows: $13 \mathrm{~g}$ of $\left(\mathrm{NH}_{4}\right)_{6} \mathrm{Mo}_{7} \mathrm{O}_{24} \cdot 4 \mathrm{H}_{2} \mathrm{O}$ was dissolved in $100 \mathrm{~mL}$ of double distilled water $\left(\mathrm{ddH}_{2} \mathrm{O}\right)$. Meanwhile, $0.35 \mathrm{~g} \quad \mathrm{~K}(\mathrm{SbO})$ $\mathrm{C}_{4} \mathrm{H}_{4} \mathrm{O}_{6} \cdot 1 / 2 \mathrm{H}_{2} \mathrm{O}$ was dissolved in $100 \mathrm{~mL}$ of $\mathrm{ddH}_{2} \mathrm{O}$. The prepared $\left(\mathrm{NH}_{4}\right)_{6} \mathrm{Mo}_{7} \mathrm{O}_{24}$ and $\mathrm{K}(\mathrm{SbO}) \mathrm{C}_{4} \mathrm{H}_{4} \mathrm{O}_{6}$ solutions were added to $300 \mathrm{~mL}$ of dilute sulfuric acid successively. Whereafter the mixed solution was stirred and stored in $4{ }^{\circ} \mathrm{C}$. Then $\mathrm{La}_{2} \mathrm{O}_{3}$ micro/nanoparticles with different morphologies were added to 15,25 , and $50 \mu \mathrm{g} \mathrm{mL}{ }^{-1}$ phosphate solution, respectively. $1 \mathrm{~mL}$ of ascorbic acid (10\%), $2 \mathrm{~mL}$ of molybdate solution and above $\mathrm{La}_{2} \mathrm{O}_{3}$ samples were mixed to determine residual $\mathrm{PO}_{4}{ }^{3-}$ according to absorbance at $710 \mathrm{~nm}$ by 752 Ultraviolet Spectrophotometer. ${ }^{\mathbf{1 8}}$

Escherichia coli (strain C43) and Staphylococcus aureus (strain TM300) were grown in Difco ${ }^{\mathrm{TM}}$ LB broth (Chemie Brunschwig) for $4 \mathrm{~h}$ at $37^{\circ} \mathrm{C}$ and gently agitation to a concentration of about

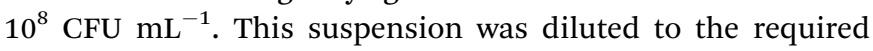
concentration with physiological saline $(0.9 \mathrm{wt} \% \mathrm{NaCl}$ in water) or where medium free (in particular phosphate free) was needed, repeatedly ( 5 times) centrifuged for $60 \mathrm{~min}$ at $\mathrm{RCF}=$ 1300 (Mistral 3000E, $2500 \mathrm{rpm}$ ). Subsequently, the supernatant was removed and the bacterial pellet was resuspended in minimal media. Minimal media was produced from $5 \mathrm{~g}$ glucose, $1 \mathrm{~g} \mathrm{NH}_{4} \mathrm{Cl}, 5.4 \mathrm{~g} \mathrm{NaCl}, 0.1 \mathrm{~g} \mathrm{MgSO}_{4}$ and $0.02 \mathrm{~g} \mathrm{CaCl}_{2}$ hexahydrate filled up to 1 liter with $\mathrm{ddH}_{2} \mathrm{O}$ and sterilized by autoclaving at $121{ }^{\circ} \mathrm{C}$ for $15 \mathrm{~min}$. To quantify the $\mathrm{CFU}$ load in a sample, a dilution row $\left(10^{-1}-10^{-8}\right)$ was plated in duplicate on dextrose agar plates (PDA, VWR BDH Prolabo). The plates were incubated at $37^{\circ} \mathrm{C}$ for $24 \mathrm{~h}$ before readout.

\section{Results and discussion}

Phase structure, morphology and formation mechanism of $\mathrm{La}_{2} \mathrm{O}_{3}$

Polyhedral, spherical and spindles-like $\mathrm{La}_{2} \mathrm{O}_{3}$ micro/ nanomaterials with hierarchical micro/nanostructures were synthesized by a simple precipitation method with urea and lanthanum nitrate. The synthesis process consists of two steps: synthesis of $\mathrm{La}(\mathrm{OH}) \mathrm{CO}_{3}$ and $\mathrm{La}_{2} \mathrm{O}_{3}$ (Scheme 1).

The morphology and microstructure of the products were characterized by SEM and TEM (shown in Fig. 1). The SEM images reveal that three different morphologies of $\mathrm{La}_{2} \mathrm{O}_{3}$ samples are successfully obtained, including polyhedral, spherical and spindles-like micro-nanostructures. The sizes of the samples are about $1 \mu \mathrm{m}, 10 \mu \mathrm{m}$ and $12 \mu \mathrm{m}$ for spherical 


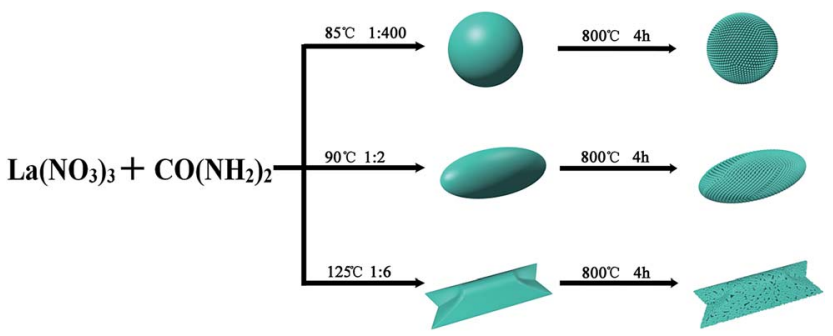

Scheme 1 Schematic illustration for preparation of micro/nanostructures $\mathrm{La}_{2} \mathrm{O}_{3}$ with a simple precipitation method using urea and lanthanum nitrate.

$\mathrm{La}_{2} \mathrm{O}_{3}$, polyhedral $\mathrm{La}_{2} \mathrm{O}_{3}$ and spindles $\mathrm{La}_{2} \mathrm{O}_{3}$ respectively. From Fig. $1 \mathrm{~A}(\mathrm{~b}), \mathrm{B}(\mathrm{e})$ and $\mathrm{C}(\mathrm{h})$, the HRTEM images reveal that the surfaces of samples are very rough. It can be further observed that the samples consist of many even smaller nanoparticles with the size of 8-15 $\mathrm{nm}$ (inset of Fig. $1 \mathrm{~A}(\mathrm{~b}), 2 \mathrm{~B}(\mathrm{e})$ and $2 \mathrm{C}(\mathrm{h})$ ), showing that the three morphologies of $\mathrm{La}_{2} \mathrm{O}_{3}$ possess hierarchical micro-nanostructures. The average diameters of the smaller nanoparticles are $8.58 \pm 0.08 \mathrm{~nm}$ for spherical $\mathrm{La}_{2} \mathrm{O}_{3}$ (Fig. $1 \mathrm{~A}\left(\mathrm{c}\right.$ )), $15.58 \pm 0.08 \mathrm{~nm}$ for polyhedral $\mathrm{La}_{2} \mathrm{O}_{3}$ (Fig. $1 \mathrm{~B}(\mathrm{f})$ ) and $13.45 \pm 0.08 \mathrm{~nm}$ for spindles-like $\mathrm{La}_{2} \mathrm{O}_{3}$ (Fig. $1 \mathrm{C}(\mathrm{i})$ ), respectively. In addition, the HRTEM shows that the values of inter planar lattice spacing are $0.29 \mathrm{~nm}, 0.31 \mathrm{~nm}$ and $0.34 \mathrm{~nm}$, respectively, corresponding to the (101), (100) and (110) plane of $\mathrm{La}_{2} \mathrm{O}_{3}$. The results further show that the prepared $\mathrm{La}_{2} \mathrm{O}_{3}$ nanocrystals belong to cubic crystalline phase, which are in agreement with the XRD results (inset of Fig. $1 \mathrm{~A}(\mathrm{~b}), 2 \mathrm{~B}(\mathrm{e})$ and $2 \mathrm{C}(\mathrm{h})$ ). In addition, the existence of detectable diffraction rings in the selected-area electron diffraction (SAED) pattern of three hierarchical nano- $\mathrm{La}_{2} \mathrm{O}_{3}$ (inset of Fig. $1 \mathrm{~A}(\mathrm{~b}), 2 \mathrm{~B}(\mathrm{e})$ and $2 \mathrm{C}(\mathrm{h})$ ) further reveal the formation of polycrystalline products. These results further confirm the formation of the hierarchical nano- $\mathrm{La}_{2} \mathrm{O}_{3}$.

The growth mechanism of the nanostructures is investigated by FESEM and TEM in time-dependent experiments. The results

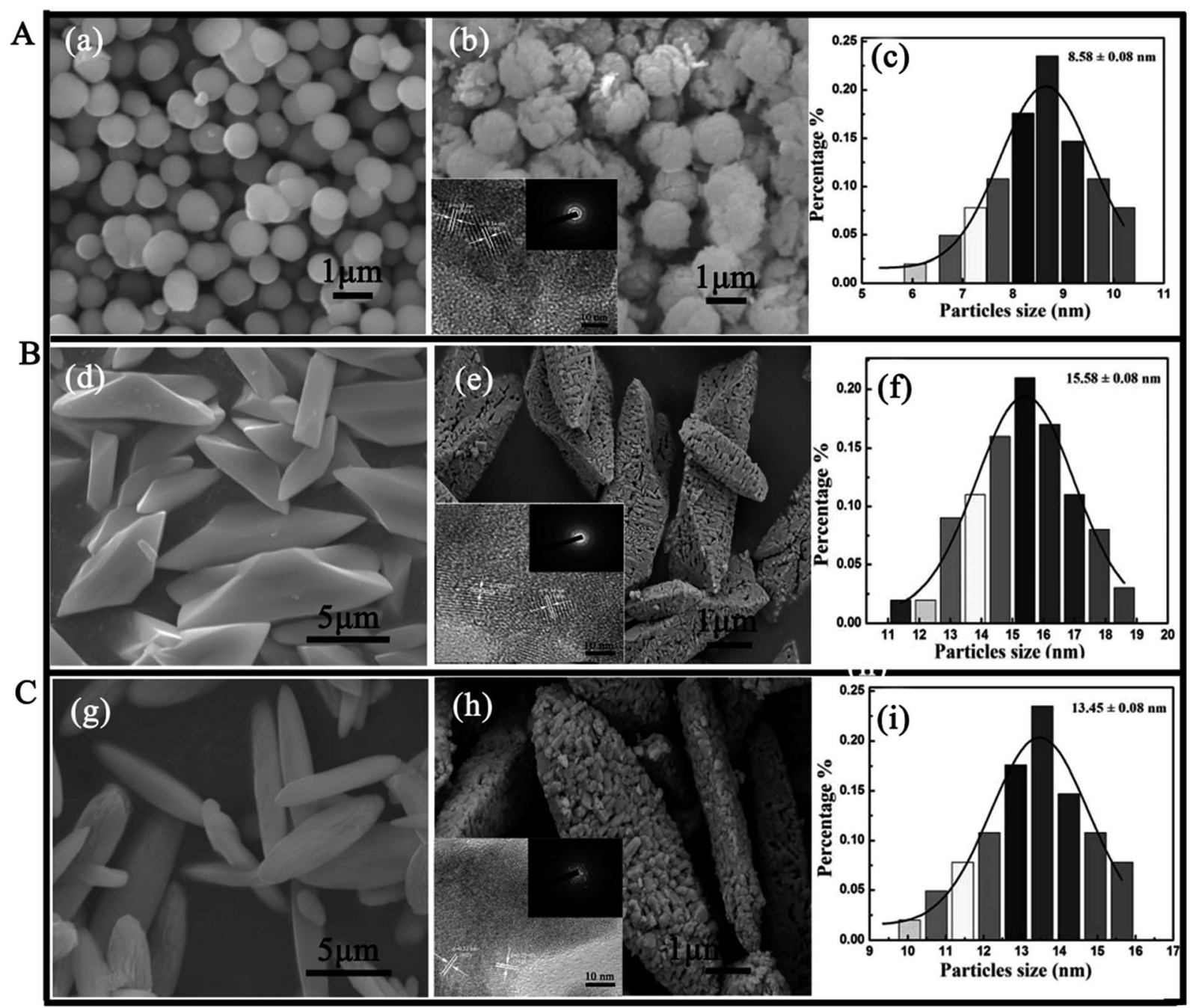

Fig. 1 SEM and particle size distribution of $\mathrm{La}_{2} \mathrm{O}_{3}$ and $\mathrm{LaOHCO}_{3}$. A(a) Spherical $\mathrm{LaOHCO}_{3} ; \mathrm{A}(\mathrm{b})$ spherical $\mathrm{La}_{2} \mathrm{O}_{3}$ (inset: lattice fringes and SAED patterns); $\mathrm{A}$ (c) size distribution analysis of hierarchically spherical nano- $\mathrm{La}_{2} \mathrm{O}_{3} ; \mathrm{B}(\mathrm{d})$ polyhedral $\mathrm{LaOHCO}_{3} ; \mathrm{B}(\mathrm{e})$ polyhedral $\mathrm{La}_{2} \mathrm{O}_{3}$ (Inset: lattice fringes and SAED patterns); $\mathrm{B}(\mathrm{f})$ Size distribution analysis of hierarchically polyhedral nano- $\mathrm{La}_{2} \mathrm{O}_{3} ; \mathrm{C}(\mathrm{g}) \mathrm{spindles}$-like $\mathrm{LaOHCO}$; $\mathrm{C}(\mathrm{h})$ spindles-like $\mathrm{La}_{2} \mathrm{O}_{3}$ (inset: lattice fringes and SAED patterns); $\mathrm{C}$ (i) Size distribution analysis of hierarchically spindles-like nano- $\mathrm{La}_{2} \mathrm{O}_{3}$. 


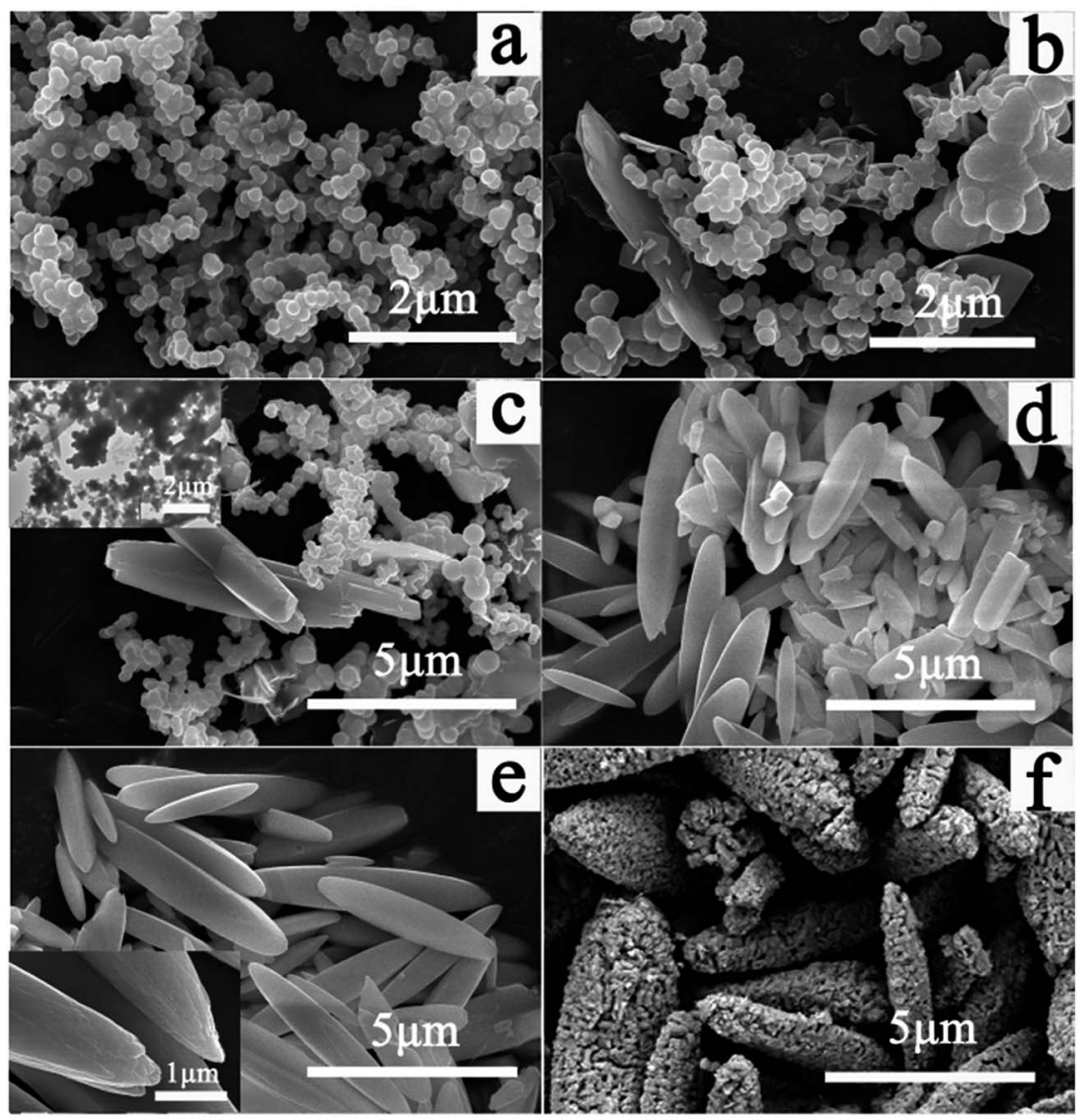

Fig. 2 The growth mechanisms of spindles-like $\mathrm{La}_{2} \mathrm{O}_{3}$ within different points-in-time: (a) $0.5 \mathrm{~h}$; (b) $1 \mathrm{~h}$; (c) $2 \mathrm{~h}$ (inset: TEM); (d) $3 \mathrm{~h}$; (e) 4 h; (f) precursors calcined from room temperature to $800^{\circ} \mathrm{C}$ for $4 \mathrm{~h}$

reveal that three different morphologies of $\mathrm{La}_{2} \mathrm{O}_{3}$ samples, including polyhedral, spherical and spindles-like, are initially derived from spherical morphology, which show similar growth mechanisms to each other. We take spindles-like $\mathrm{La}_{2} \mathrm{O}_{3}$ for example to explain the growth mechanism in details (shown in Fig. 2). Initially, the $\mathrm{La}(\mathrm{OH}) \mathrm{CO}_{3}$ precursors of spherical morphology are formed within 0.5 hour reaction time (Fig. 2a), similarly to the formations of polyhedral and spherical $\mathrm{La}_{2} \mathrm{O}_{3}$ samples. Then, more $\mathrm{La}(\mathrm{OH}) \mathrm{CO}_{3}$ precursor products of spherical morphology assemble to form spindles-like morphology via oriented attachment within 1-3 hours (Fig. 2b-e). Meanwhile, non hollow structures are observed by characterization of TEM (inset of Fig. 2c). Then, we find spindles-like $\mathrm{La}(\mathrm{OH}) \mathrm{CO}_{3}$ precursors consist of small particles (inset of Fig. 2e). Finally, the $\mathrm{La}(\mathrm{OH}) \mathrm{CO}_{3}$ precursors are calcined from room temperature to $800{ }^{\circ} \mathrm{C}$ and maintained at this temperature for $4 \mathrm{~h}$ to form $\mathrm{La}_{2} \mathrm{O}_{3}$ samples with micro/nanostructures (Fig. 2f). The growth mechanisms of polyhedral and spherical products are also researched in time-dependent experiments. The similar growth mechanisms are observed.

XRD patterns of three samples are very similar, one of which is depicted in Fig. 3A as a representation. From Fig. 3A, a strong intensity peak is detected at a diffraction angle of $30^{\circ}$, which is assigned to (101) plane of $\mathrm{La}_{2} \mathrm{O}_{3}$. The other five peaks are assigned to (100), (002), (102), (110) and (103) lattice planes belonging to cubic crystalline phase of $\mathrm{La}_{2} \mathrm{O}_{3}$ (JCPDS no. 26-0815). The results indicate that the pure $\mathrm{La}_{2} \mathrm{O}_{3}$ crystals are successfully prepared by the simple method. Representative FTIR spectra of spherical $\mathrm{La}_{2} \mathrm{O}_{3}$ and $\mathrm{La}(\mathrm{OH}) \mathrm{CO}_{3}$ precursor are shown in Fig. 3B. In the spectrum of $\mathrm{La}(\mathrm{OH}) \mathrm{CO}_{3}$, the bands at 1486 and $1412 \mathrm{~cm}^{-1}$ are attributed to the stretching vibration mode of the $\mathrm{C}-\mathrm{O}$ bond, and the flexural vibration of $\mathrm{CO}_{3}{ }^{2-}$ appear at $859 \mathrm{~cm}^{-1}, 720 \mathrm{~cm}^{-1}, 695 \mathrm{~cm}^{-1}$. In the spectrum of $\mathrm{La}_{2} \mathrm{O}_{3}$, the La-O stretching vibration is at about $653 \mathrm{~cm}^{-1}$, showing $\mathrm{La}_{2} \mathrm{O}_{3}$ is prepared successfully. The thermogravimetric analysis (TGA) and differential temperature analysis (DTA) traces disclosed the formation process of $\mathrm{La}_{2} \mathrm{O}_{3}$ from pyrolysis of the $\mathrm{La}(\mathrm{OH}) \mathrm{CO}_{3}$ precursor. The TGA curves of the as-prepared $\mathrm{La}(\mathrm{OH}) \mathrm{CO}_{3}$ are shown in Fig. 3C. It can be noticed that there are three weight loss steps around $250{ }^{\circ} \mathrm{C}$ to $300{ }^{\circ} \mathrm{C}, 450{ }^{\circ} \mathrm{C}$ to $500{ }^{\circ} \mathrm{C}$ and 700 to $790{ }^{\circ} \mathrm{C}$. For $\mathrm{La}(\mathrm{OH}) \mathrm{CO}_{3}$, the weight loss between $250{ }^{\circ} \mathrm{C}$ to $300{ }^{\circ} \mathrm{C}$ could be attributed to the removal of water, accompanying the formation of $\mathrm{La}_{2} \mathrm{O}\left(\mathrm{CO}_{3}\right)_{2}$ (see reaction (1)). Then $\mathrm{La}_{2} \mathrm{O}\left(\mathrm{CO}_{3}\right)_{2}$ decomposes to form $\mathrm{La}_{2} \mathrm{O}_{3}$ and release $\mathrm{CO}_{2}$, approximately to lose weight $28 \%$ (see reaction (2) and (3))

$$
\begin{aligned}
2 \mathrm{LaOHCO}_{3} & \rightarrow \mathrm{La}_{2} \mathrm{O}\left(\mathrm{CO}_{3}\right)_{2}+2 \mathrm{H}_{2} \mathrm{O} \\
\mathrm{La}_{2} \mathrm{O}\left(\mathrm{CO}_{3}\right)_{2} & \rightarrow \mathrm{La}_{2} \mathrm{O}_{2} \mathrm{CO}_{3}+\mathrm{CO}_{2}
\end{aligned}
$$



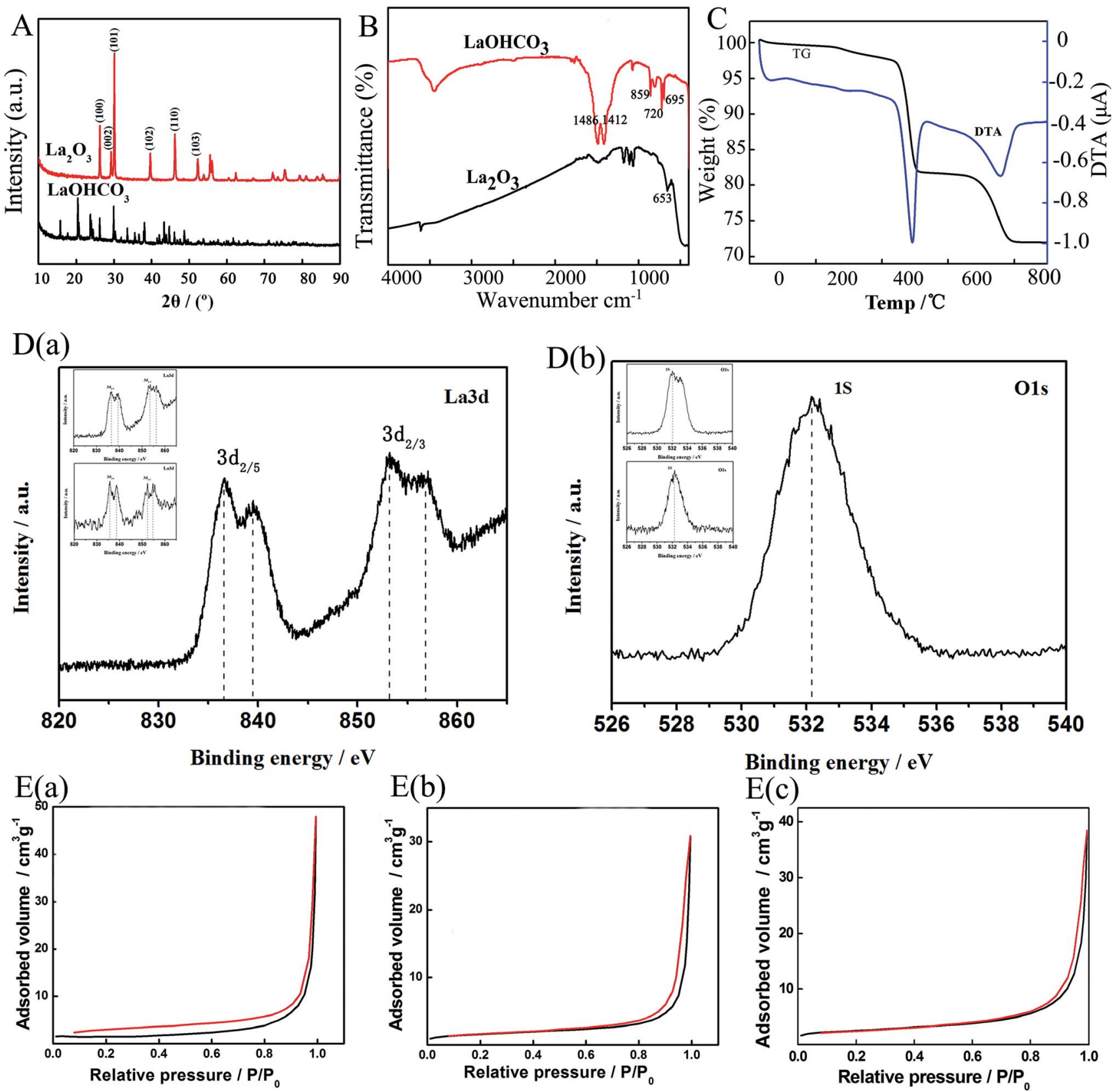

$\mathrm{E}(\mathrm{c})$

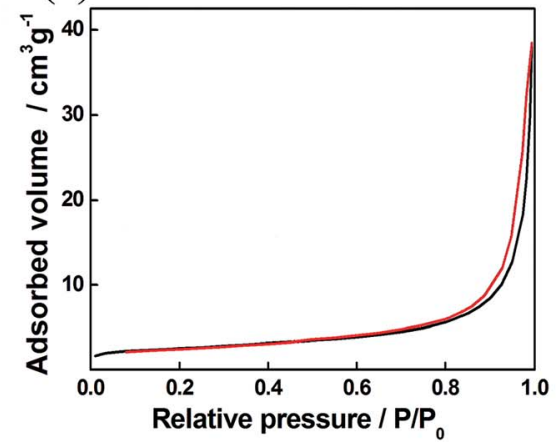

Fig. 3 (A) XRD patterns of polyhedral $\mathrm{La}_{2} \mathrm{O}_{3}$ and $\mathrm{LaOHCO}_{3}$. The top red line depicts the diffraction pattern of $\mathrm{La}_{2} \mathrm{O}_{3}$ nanocrystals, whereas the lower black line corresponds to $\mathrm{LaOHCO}_{3}$ nanocrystals; (B) FTIR of the spindles $\mathrm{La}_{2} \mathrm{O}_{3}$ and $\mathrm{LaOHCO}_{3}$; (C) the thermogravimetric (TG) and DTA of $\mathrm{LaOHCO}_{3}$; (D) XPS spectra of (a) La 3d, (b) O 1s; (E) $\mathrm{N}_{2}$-sorption isotherms and pore size distribution curves (inset) for different morphology micro-nano $\mathrm{La}_{2} \mathrm{O}_{3}$. (a) Spherical $\mathrm{La}_{2} \mathrm{O}_{3}$, (b) polyhedral $\mathrm{La}_{2} \mathrm{O}_{3}$, (c) spindle-like $\mathrm{La}_{2} \mathrm{O}_{3}$.

$$
\mathrm{La}_{2} \mathrm{O}_{2} \mathrm{CO}_{3} \rightarrow \mathrm{La}_{2} \mathrm{O}_{3}+\mathrm{CO}_{2}
$$

Fig. 3D presents the X-ray photoelectron spectroscopies of $\mathrm{La}_{2} \mathrm{O}_{3}$. These spectra exhibit characteristic La $3 \mathrm{~d}$ and $\mathrm{O} 1 \mathrm{~s}$ peaks. As indicated in Fig. 3D(a), the La 3d spectrum shows two peaks at the binging energy 839.48 and $856.77 \mathrm{eV}$, corresponding to $\mathrm{La}$ $3 \mathrm{~d}_{5 / 2}$ and $3 \mathrm{~d}_{3 / 2}$, respectively. Meanwhile, the peaks located at a binding energy of around 528.9 and $531.65 \mathrm{eV}$ are both corresponding to the $\mathrm{La}_{2} \mathrm{O}_{3}$ and $\mathrm{H}_{2} \mathrm{O}$ spectrum (Fig. $3 \mathrm{D}(\mathrm{b})$ ). These results are in accordance with the previous reports on $\mathrm{La}_{2} \mathrm{O}_{3} \cdot{ }^{19}$
Brunauer-Emmett-Teller (BET) gas adsorption measurements were used to characterize pore volume, pore diameter and specific surface area (see Fig. $3 \mathrm{E}$ ). The $\mathrm{N}_{2}$ adsorption/ desorption isotherms of the synthesized $\mathrm{La}_{2} \mathrm{O}_{3}$ exhibit typical type-IV hysteresis, indicating the presence of pores (Fig. 3E). The samples are mainly mesoporous (inset of Fig. 3E). The BET surface area is measured to be $18.76 \mathrm{~m}^{2} \mathrm{~g}^{-1}$ for spherical $\mathrm{La}_{2} \mathrm{O}_{3}$, $12.43 \mathrm{~m}^{2} \mathrm{~g}^{-1}$ for polyhedral $\mathrm{La}_{2} \mathrm{O}_{3}$ and $8.14 \mathrm{~m}^{2} \mathrm{~g}^{-1}$ for polyhedral $\mathrm{La}_{2} \mathrm{O}_{3}$, respectively.

To determine absorption capacity of $\mathrm{La}_{2} \mathrm{O}_{3}$ micronanostructures for phosphate, ascorbic acid and molybdate 

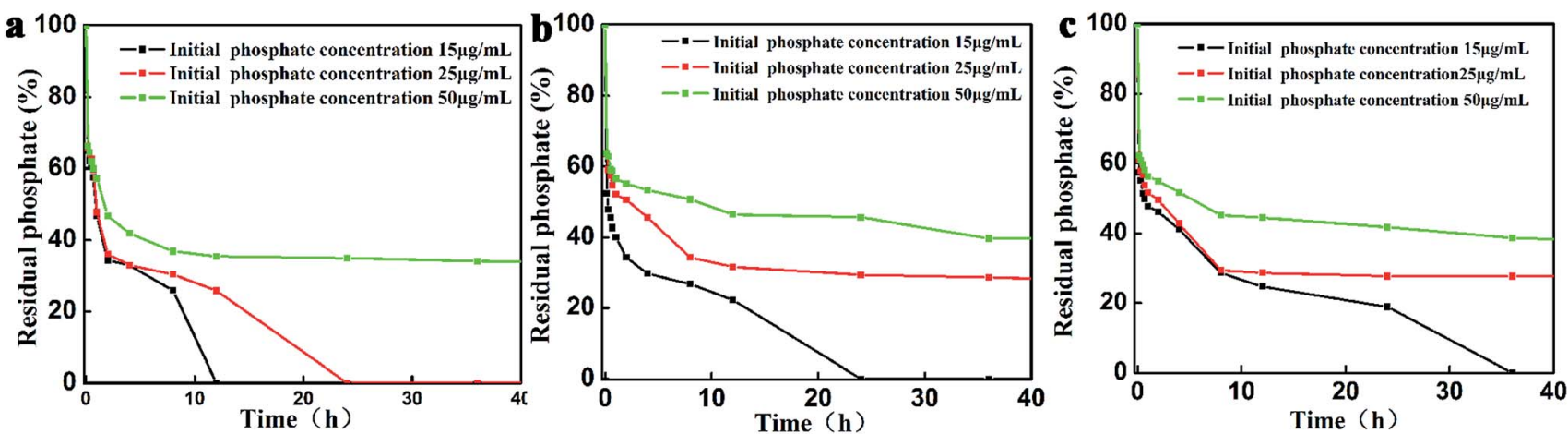

Fig. 4 Phosphate absorption capacity of different morphology micro-nano $\mathrm{La}_{2} \mathrm{O}_{3}$. (a) Spherical $\mathrm{La}_{2} \mathrm{O}_{3}$, (b) spindle-like $\mathrm{La}_{2} \mathrm{O}_{3}$, (c) polyhedral $\mathrm{La}_{2} \mathrm{O}_{3}$. Black wire, red wire and green wire: initial phosphate concentration is $15 \mu \mathrm{g} \mathrm{m}^{-1}, 25 \mu \mathrm{g} \mathrm{mL}{ }^{-1}$ and $50 \mu \mathrm{g} \mathrm{mL} \mathrm{L}^{-1}$ respectively.

solution were employed to measure phosphate group. The initial concentrations of phosphate were $15 \mu \mathrm{g} \mathrm{mL} \mathrm{m}^{-1}$, $25 \mu \mathrm{g} \mathrm{mL} \mathrm{m}^{-1}$ and $50 \mu \mathrm{g} \mathrm{mL} \mathrm{L}^{-1}$, respectively. As shown in Fig. 4, the residual phosphate reduce when $\mathrm{La}_{2} \mathrm{O}_{3}$ was added. It is worth highlighting that phosphate is absolutely removed by spherical $\mathrm{La}_{2} \mathrm{O}_{3}$ for only $12 \mathrm{~h}$ (Fig. 4a black wire) when initial phosphate concentration is $15 \mu \mathrm{g} \mathrm{mL}{ }^{-1}$, while $24 \mathrm{~h}$ for spindles-like micronano $\mathrm{La}_{2} \mathrm{O}_{3}$ (Fig. $4 \mathrm{~b}$ black wire), $35 \mathrm{~h}$ for polyhedral $\mathrm{La}_{2} \mathrm{O}_{3}$ (Fig. 4c black wire). Moreover, when initial phosphate concentration is $25 \mu \mathrm{g} \mathrm{mL}{ }^{-1}$ (red wire), phosphate removal have been accomplished completely by spherical $\mathrm{La}_{2} \mathrm{O}_{3}$ after $24 \mathrm{~h}$, but accomplished $68 \%$ by spindle-like $\mathrm{La}_{2} \mathrm{O}_{3}$ and $78 \%$ by polyhedral $\mathrm{La}_{2} \mathrm{O}_{3}$ in the meantime. Likewise, superior removal capacity of spherical $\mathrm{La}_{2} \mathrm{O}_{3}$ is observed, when initial phosphate concentration is $50 \mu \mathrm{g} \mathrm{mL} L^{-1}$. The results show that spherical $\mathrm{La}_{2} \mathrm{O}_{3}$ has best phosphate removal capacity from water, which attributes to that the spherical $\mathrm{La}_{2} \mathrm{O}_{3}$ has the smallest particle sizes and the largest BET surface area.

To investigate the effect of phosphate addition and phosphate starvation on microorganism growth, the growth curve of Escherichia coli (a Gram-negative bacteria) and Staphylococcus aureus (a Gram-positive bacteria) were analyzed. Meanwhile, residual phosphate was calculated after microorganism grows for $8 \mathrm{~h}$. As shown in Fig. $5 \mathrm{a}$, the phosphate addition is beneficial to microorganisms growth (both Gram-positive and Gramnegative bacteria) (Fig. $5 a$ and b). It is about 32 times and 26
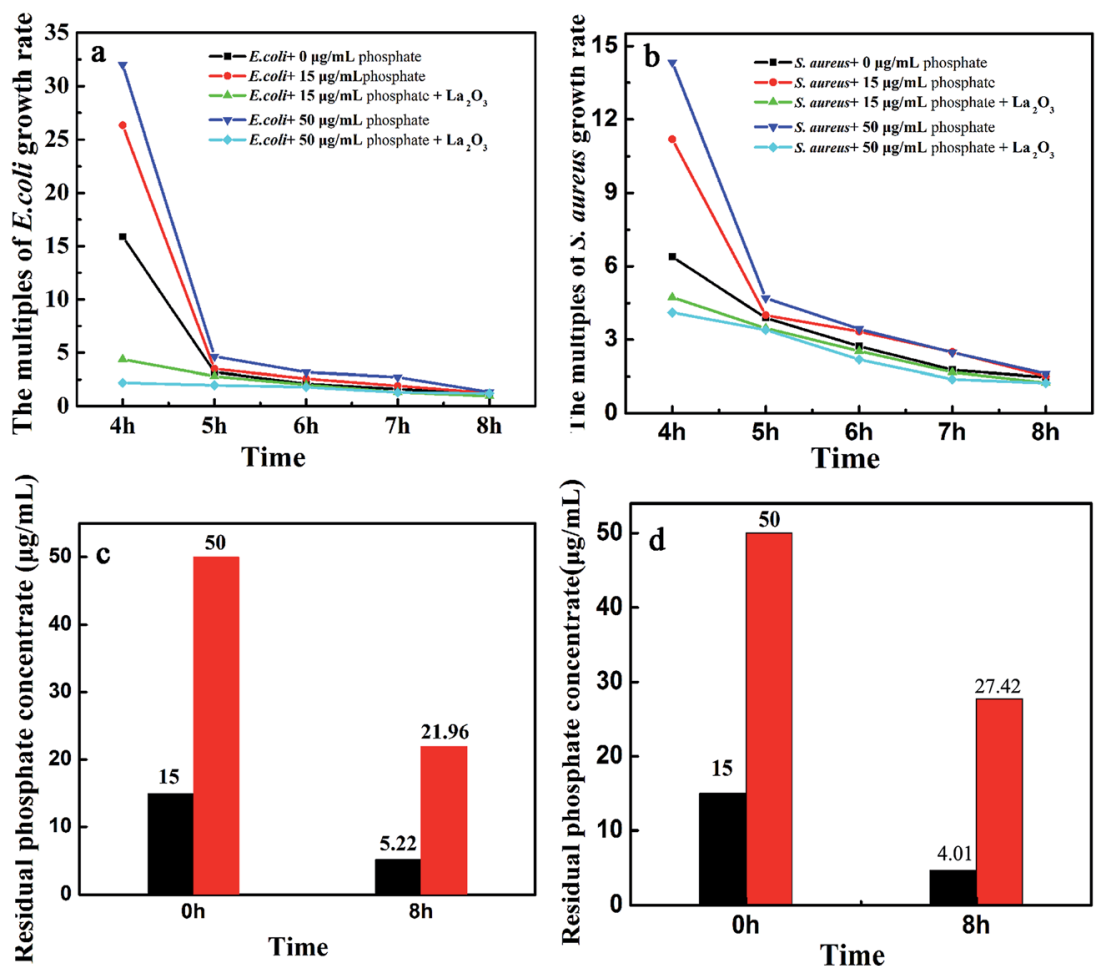

Fig. 5 Antibacterial activity (Escherichia coli and Staphylococcus aureus) and phosphate adsorption of spherical $\mathrm{La}_{2} \mathrm{O}_{3}(\mathrm{a}, \mathrm{c})$ Escherichia coli, (b, d) Staphylococcus aureus. 
times larger than the growth rate of $E$. coli in $2 \mathrm{~h}$ when adding

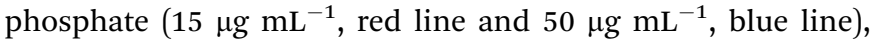
showing that phosphate addition to minimal medium could be beneficial to growth of Escherichia coli (Fig. 5a) and Staphylococcus aureus (Fig. 5b) when growth less than $5 \mathrm{~h}$. However, the benefit of phosphate is suppressed following the addition of $\mathrm{La}_{2} \mathrm{O}_{3}$. The growth rates of Escherichia coli (Gram-negative bacteria) and Staphylococcus aureus (Gram-positive bacteria) were drawn in Fig. 5a-d. From Fig. 5a, it is only 5 and 2.5 times larger than the growth rate of $E$. coli in $2 \mathrm{~h}$ when adding $\mathrm{La}_{2} \mathrm{O}_{3}$ to medium in $4 \mathrm{~h}$ although the existence of phosphate $\left(15 \mu \mathrm{g} \mathrm{mL} \mathrm{L}^{-1}\right.$ and $50 \mu \mathrm{g} \mathrm{mL} \mathrm{m}^{-1}$ ). The results show that the growth rates of E. coli and $S$. aureus are obviously limited within $5 \mathrm{~h}$ when $\mathrm{La}_{2} \mathrm{O}_{3}$ is added, attributed to effective binding of $\mathrm{La}_{2} \mathrm{O}_{3}$ to phosphate, namely that phosphate starvation results in limited microbial growth. Given this, phosphate removal ability capacity of three morphology micro-nano $\mathrm{La}_{2} \mathrm{O}_{3}$ could be a key point to compare antimicrobial properties of $\mathrm{La}_{2} \mathrm{O}_{3}$. Due to superior removal capacity of spherical $\mathrm{La}_{2} \mathrm{O}_{3}$, spherical $\mathrm{La}_{2} \mathrm{O}_{3}$ exhibited better antibacterial property than other two morphologies $\mathrm{La}_{2} \mathrm{O}_{3}$. It means that phosphate absorption capacity of $\mathrm{La}_{2} \mathrm{O}_{3}$ is consistent with the antibacterial property of $\mathrm{La}_{2} \mathrm{O}_{3}$.

\section{Conclusion}

We successfully obtained shape-controlled (spindle, polyhedron, and sphere) micrometer-scaled $\mathrm{La}_{2} \mathrm{O}_{3}$, hierarchically assembled by nanoparticles, through a facile, high quality and low prices method. Meanwhile, they have strong removal ability for phosphate and excellent antibacterial property, especially for sphere micro-nano structure $\mathrm{La}_{2} \mathrm{O}_{3}$. These hierarchical $\mathrm{La}_{2} \mathrm{O}_{3}$ micro-nanomaterials may have very good application prospects in water pollution of eutrophication, or reduce excess phosphate in human body in biomedical areas.

\section{Conflicts of interest}

There are no conflicts to declare.

\section{Acknowledgements}

This work was financially supported by the National Natural Science Foundation of China (21571053), the Program for Innovative Research Team in Science and Technology in University of Henan Province (18IRTSTHN002), Key Scientific Research Project of Higher Education of Henan Province (18A150046), the 111 project (D17007).

\section{References}

1 S. I. Boldish and W. B. White, Vibrational spectra of crystals with the A-type rare earth oxide structure. $\mathrm{La}_{2} \mathrm{O}_{3}$ and $\mathrm{Nd}_{2} \mathrm{O}_{3}$, Spectrochim. Acta, Part A, 1979, 35, 1235.

2 J. Gouteron, D. Michel, A. M. Lejus and J. Zarembowitch, Raman spectra of lanthanide sesquioxide single crystals: Correlation between A and B-type structures, J. Solid State Chem., 1981, 38, 288.
3 S. W. Kang and S. W. Rhee, Deposition of $\mathrm{La}_{2} \mathrm{O}_{3}$ Films by Direct Liquid Injection Metallorganic Chemical Vapor Deposition, J. Electrochem. Soc., 2002, 149, 345.

4 A. M. De Asha, J. T. S. Critchley and R. M. Nix, Molecular adsorption characteristics of lanthanum oxide surfaces: the interaction of water with oxide overlayers grown on $\mathrm{Cu}$ (111), Surf. Sci., 1998, 405, 201.

5 W. Harder and L. Dijkhuizen, Physiological Responses to Nutrient Limitation, Rev. Microbiol., 1983, 37, 1.

6 T. F. Thingstad, U. L. Zweifel and R. F. Limnol, P limitation of heterotrophic bacteria and phytoplankton in the northwest Mediterranean T. Frede Thingstad, Limnol. Oceanogr., 1998, 43, 88.

7 C. V. Cardemil, D. R. Smulski, R. A. Larossa and A. C. Vollmer, Vollmer. Bioluminescent Escherichia coli Strainsfor the Quantitative Detection of Phosphate and Ammoniain Coastal and Suburban Watersheds, DNA Cell Biol., 2010, 29, 519.

8 L. C. Gerber, N. Moser, N. A. Luechinger, W. J. Stark and R. N. Grass, Phosphate starvation as an antimicrobial strategy: the controllable toxicity of lanthanum oxide nanoparticles, Chem. Commun., 2012, 48, 3869.

9 M. Kasmi, M. Hamdi and I. Trabelsi, Eco-friendly process combining physical-chemical and biological technics for the fermented dairy products waste pretreatment and reuse, Water Sci. Technol., 2017, 75, 39.

10 F. Haghseresht, S. Wang and D. D. Do, A novel lanthanummodified bentonite, Phoslock, for phosphate removal from wastewaters, Appl. Clay Sci., 2009, 46, 369.

11 M. M. Gibbs, C. W. Hickey and D. Oezkundakci, Sustainability assessment and comparison of efficacy of four P-inactivation agents for managing internal phosphorus loads in lakes: sediment incubations, Hydrobiologia, 2011, 658, 253.

12 M. J. Barry and B. J. Meehan, The acute and chronic toxicity of lanthanum to Daphnia Carinata, Chemosphere, 2000, 41, 1669.

13 M. Lürling and F. V. Oosterhout, Controlling Eutrophication by Combined Bloom Precipitation and Sediment Phosphorus Inactivation, Water Res., 2013, 47, 6527.

14 J. J. He, W. Wang, F. L. Sun, W. X. Shi, D. P. Qi, K. Wang, R. S. Shi, F. Y. Cui, C. Wang and X. D. Chen, Highly Efficient Phosphate Scavenger Based on Well-Dispersed $\mathrm{La}(\mathrm{OH})_{3}$ Nanorods in Polyacrylonitrile Nanofibers for Nutrient-Starvation Antibacteria, ACS Nano, 2015, 9, 9292.

15 J. Xie, Y. Lin, C. J. Li, D. Y. Wu and H. N. Kong, Removal and recovery of phosphate from water by activated aluminum oxide and lanthanum oxide, Powder Technol., 2015, 269, 351.

16 M. A. H. Johir, T. T. Nguyen, K. Mahatheva, M. Pradhan, H. H. Ngo, W. Guo and S. Vigneswaran, Removal of phosphorus by a high rate membrane adsorption hybrid system, Bioresour. Technol., 2016, 201, 365.

17 D. L. Correll, The Role of Phosphorus in The Eutrophication of Receiving Waters: A Review, J. Environ. Qual., 1998, 27, 261. 
18 P. P. Veerle, J. B. Geert, R. B. An, E. D. B. Marc and C. D. Patrick, Lanthanum: A Safe Phosphate Binder, Semin. Dial., 2006, 19, 195.

19 Y. Gao, Y. Zhang, Y. Zhou, C. Zhang, H. Zhang, S. Zhao, J. Fang, M. Huang and X. Sheng, Synthesis of ordered mesoporous La2O3-ZrO2 composites with encapsulated $\mathrm{Pt}$ NPs and the effect of La-dopping on catalytic activity, $J$. Colloid Interface Sci., 2017, 503, 178. 